\title{
The Association of Calcium Profiles at Calving with Health and Performance of Holstein Cows and Their Calves
}

\author{
Constantin Găvan ${ }^{1}$ \& Mihaela Riza ${ }^{1}$ \\ ${ }^{1}$ Agriculture Research and Development Station Simnic - Craiova, Dolj, Romania \\ Correspondence: Constantin Găvan, Agriculture Research and Development Station Simnic - Craiova, Şoseaua \\ Bălcești, 54, Dolj, Romania. Tel: 40-025-141-7534. E-mail: scda_simnic@yahoo.com
}

Received: October 5, $2021 \quad$ Accepted: October 20, $2021 \quad$ Online Published: November 1, 2021

The research is financed by Agriculture Research and Development Station Simnic - Craiova.

\begin{abstract}
The aim of this study was to assess the association of hypocalcemia at calving with health and performance of Holstein cows and their calves. Data were collected January $1^{\text {st }} 2017$ to December $31^{\text {st }} 2020$. A total of 431 lactating Holstein Friesian cows (118 primiparous and 313 multiparous) from a research of hypocalcemia was 2 groups (hypo and non-hypo). The overall prevalence of hypocalcemia was $3.4 \%$ for first-lactation cows and $18 \%$ for multiparous cows. Lactating dairy cows with hypocalcemia had greater proportion of cows with Retained Fetal Membranes (RFM) metritis and culling within 60 days in milk (DIM), compared with non-hypocalcemia respectively. For the first 2 official milk tests milk yield and components ( $\%$ fat, $\%$ protein on SCC) did not differ between hypo and non-hypo cows. The days in milk at first service, mastitis, dystocia and pregnancy at first service were not different between hypo and non-hypo groups. The proportion of stillbirth, survival at 60 days of age in calves did not differ between calves born from hypo or non-hypo cows. Calves born from Hypo cows had greater incidence of diarrhea (38.3\%) than calves born (22.3\%) from non-hypo cows. The results of this study show that hypocalcemia in calving has significant health implications for both dams and their calves.
\end{abstract}

Keywords: hypocalcemia, retained fetal membranes, metritis, diarrhea

\section{Introduction}

The dairy cow undergoes a transition from non-lactating to lactating at calving. The animal is tremendously challenged to maintain calcium homeostasis. Those that fail can develop hypocalcemia, a common metabolic disorder in dairy cows that leads to an increased risk of detrimental health. Physiologically, serum calcium concentration in adult cow is maintained above $2.0 \mathrm{mmol} / \mathrm{L}$ (Martin-Tereso and Verstegen, 2011). Before calving, the cow has a calcium requirement for maintenance and an added requirement for fetal growth. After calving, the condition for pregnancy is exchanged for an addition for the colostrum and milk production. This increases the total need of calcium by approximately 100\% (Ferneberg, 2010). Due to the start of colostrum production and consequently increasing calcium demand the nadir of serum concentration occurs 12 to 24 hours after parturition (Goff, 2008).

Calcium ions play a very important role in many fundamental biological processes in the cow body, such as muscle concentration, blood coagulation and hormone release, and are structural components of the skeleton. Most of the calcium (99\%) in the body is stored in bone, and a minor part $(0.1 \%)$ is present in the extracellular fluid. The remainder is in plasma membrane and in the endoplasmic reticulum. In cow's colostrum the concentration of total calcium is approximately $42-58 \mathrm{mmol} / 1$ (Goff et al. 2000), and milk is lower, approximately $30 \mathrm{mmol} / 1$ (Sjaostad et al., 2003). The total concentration of calcium in blood plasma is maintained between 2.1 and $2.5 \mathrm{mmol} / 1$ (Goff, 2008) in the adult cows.

To maintain calcium homeostasis after calving at the start of lactation, the cow will increase reabsorption in the kidneys, increase absorption in the intestine and withdraw calcium from bone (Goff, 2008). Bone calcium mobilization and renal reabsorption are induced by secretion of parathyroid hormone (PTH). The increased intestinal absorption is induced by 1.25-dihydroxyvitamin $\mathrm{D}$, which is produced in the kidneys in response to increase PTH levels. 
Practical animal nutrition often considers nutrient absorption to be a constant competence; however, Ca absorption is constantly changing due to endogenous signals and external from the diet. Ramberg et al., 1970, described Ca homeostasis as a system with „controlled signals, disturbing signals and controlling signals ${ }^{\text {ee }}$. This approach suggests that the cause of hypocalcemia could be delay in adaptive mechanisms (,,controlling signals ${ }^{\mathrm{ec}}$ ) that cannot provide timely responses to the sudden changes in Ca clearance from the blood (Martin-Tereso and Verstegen, 2011). The adaptive mechanisms involve renal reabsorption, gastrointestinal absorption and bone turnover. Renal reabsorption and intestinal absorption are both regulated processes of transepithelial $\mathrm{Ca}$ transport. Bone turnover is a tissue modification process that is regulated in such a way that it can respond anabolically or catabolically to sustain Ca homeostasis while maintaining the structural function of bone (Martin-Tereson and Verstegen, 2011). $\mathrm{Ca}$ reabsorption in the kidney and active gastro epithelial absorption are transcellular processes that coordinated by the hormonal $\mathrm{Ca}$ homeostatic system and that transports $\mathrm{Ca}$ into the blood. This transcellular transport of $\mathrm{Ca}$ consists of three steps: entry into epithelial cells, intracellular diffusion mediated by binding protein and active transport from the cell into the next extracellular compartment (Hoenderop et al., 2005). Ca enters the epithelial cells through two transient receptor potential vanillaid (TRPV) channels (TRPV5 and TRPV6), and this Ca entry represents the limiting key regulatory step of the process, and is strongly regulated by calcitriol (Boulin et al., 2003) and extracellular Ca concentration (Nilius et al., 2002). Inside the epithelial cell, Ca diffuses through the cytoplasm mediated by two cytosolic Ca-binding proteins, calbindin - D9K and calbindin - 28k (Hoenderop et al., 2005). This second step can limit transport across the cell because the lack of calbindin proteins impedes Ca transport (Bronner, 2003).

The third step in transcellular transport is $\mathrm{Ca}$ export out of the cell into the bloodstream, and this process is mediated by ATP via $\mathrm{Ca}^{2+}$ - ATPase protein, and the $\mathrm{Na}^{+} / \mathrm{Ca}^{2+}$ exchanger. This step is also regulated by calcitriol. Calcitriol is the active form of vitamin $\mathrm{D}$, also known as 1.25-dihydroxycholecalciferol. There are molecular differences between renal and intestinal transcellular $\mathrm{Ca}$ transport. The $\mathrm{Ca}$ entry channel in the intestine is TRPV6 (Suzuki; et al., 2008) Whereas TRPV5 is in the kidney (Khanal and Nemere, 2008). The predominant intracellular Ca-binding protein in the kidney is calbindin- $\mathrm{D}_{28 \mathrm{~K}}$ and calbindin- $\mathrm{D}_{9 \mathrm{~K}}$ in the intestine (Bouillon et al., 2003).

A characteristic of TRPV5 is its pH sensitivity. During metabolic acidosis TRPV5 has approximately half of its normal activity (Suzuki et al., 2008). This inhibition result in hypercalciuria, a condition in cows fed low-dietary cation-anion differences diets (Schonewille et al. 1994; Roche et al., 2003).

Bone remodeling is an important adaptive mechanism of $\mathrm{Ca}$ homeostatic control. Bone $\mathrm{Ca}$ represents a quantitatively large source that sustain blood $\mathrm{Ca}$ levels in periods of $\mathrm{Ca}$ deficit in early cow lactation. The hormone affecting bone remodeling is PTH and its action is coordinated with calcitriol (Parfitt, 1976). The PTH initiates bone resorption to compensate for decreases in blood $\mathrm{Ca}$, and in the same time, it induces the synthesis of calcitriol, which activates intestinal $\mathrm{Ca}$ absorption. If blood $\mathrm{Ca}$ is normalized by intestinal input, PTH ceases and consequently induces renal excretion of the surplus.

In conclusion intestinal absorption and bone resorption present a delay of approximately 1 or 2 days when adapting to an increased $\mathrm{Ca}$ clearance from the blood. This time coincides with the period at calving when cows suffer from hypocalcemia.

For many years, dairy nutritionists have searched for a dietary strategy to prevent hypocalcemia. Dietary preventive strategies and nutritional risk factors have been reviewed (Bauman and Bruce Currie, 1980). Implementation of low-Ca diets as a specific strategy for hypocalcemia has practical difficulties (is a difficult to formulate a dry cow ration below $1.5 \mathrm{~g} \mathrm{Ca}$ per $\mathrm{kg} \mathrm{DM}$ ). Supplying anionic salts is a preventive dietary intervention. The effect of the DCAD (Dietary Cation-Anion Differences) levels on hypocalcemia has been evaluated (Lean et al., 2006). The objectives of feeding prepartum cows acidogenic diets is to induce a compensated metabolic acidosis.

The transient hypocalcemia at calving is associated with increased risk of uterine and metabolic disorders (Martinez et al., 2012).

Subclinical hypocalcemia affected reproductive performance such as estrus cyclicity (Ribeiro et al., Caixeta et al., 2017) and pregnancy rate to first AI (Chapinal et al. 2012).

Calves born from hypocalcemia cows have been reported to be at greater risk of developing diarrhea and respiratory events during neonatal period, compared with calves born from non-hypo calcemic cows (Planski and Abrashev, 1987).

Wilhelm et al. (2017) reported that calves born from hypo calcemic cows had greater incidence of diarrhea (49\%) than calves born (33.3\%) from non-hypo calcemic cow under certified organic management. 
The objective of this study was to assess the association of hypocalcemia (Hypo) of cows at calving with survival, health and performance of lactating dairy cows and their calves in a research dairy herd.

\section{Method}

\subsection{Animals Feeding and Facilities in the Research Farm}

Dairy cows and heifers are housed in barns with access to dry-lot, prepartum and postpartum. All cows are milked twice daily in approximately $12 \mathrm{~h}$ interval. Cows and heifers were fed in the morning and afternoon with diets formulated to meet or to exceed nutritional requirements for dry and lactating dairy cows. Additionally, all cows and heifers have access to pasture (alfalfa or ryegrass). Prepartum and postpartum diets were presented in table 1.

Table 1. Prepartum and postpartum dairy cow diets (DM basis).

\begin{tabular}{lcc}
\hline \multicolumn{1}{c}{ Item } & $\begin{array}{c}\text { Prepartum } \\
\%\end{array}$ & $\begin{array}{c}\text { Postpartum } \\
\%\end{array}$ \\
\cline { 2 - 3 } A. Ingredient: & 26 & 29 \\
\hline Alfalfa hay & 45 & 5.5 \\
Grass hay & 10 & 16 \\
Corn silage & 16 & 47 \\
Grain mix & 3 & 2.5 \\
Mineral mix & 100 & 100 \\
\hline TOTAL & & \\
\hline Nutrient profile: & 1.28 & 1.60 \\
\hline Net energy lactation & 12 & 19 \\
Crude protein & 46 & 28 \\
Neutral detergent fiber & 40 & 20 \\
Acid detergent fiber & 14 & 27 \\
Starch & 1.4 & 1.3 \\
Calcium & 0.3 & 0.4 \\
Phosphorus & 0.4 & 0.4 \\
Magnesium & 1.5 & 1.3 \\
Kalium & 0.3 & 0.4 \\
Natrium & 1.1 & 0.4 \\
Chloride & 0.4 & 0.2 \\
Sulfa & -5 & 26.9 \\
DCAD mEq/100g of $\mathrm{DM}^{*}$ &
\end{tabular}

Pregnant cows were dried-off $60 \pm 10$ days before the expected calving date and were moved in a dry pen after last milking. At $21 \pm 3$ days before the expected calving date the pregnant cows were moved to prepartum pens. In the prepartum pens all cows closely monitored by on farm personnel for signs of parturition every 1 hour. Calving ease of cows is recorded using a 4-point scale ( $1=$ no assistance; 2 = assistance by 1 person without the use of mechanical traction; 3 = mechanical extraction; and $4=$ sever dystocia - surgery or fetology needed). Calving date and time and stillbirth are recorded. After calving all cows has their BCS assessed using a 5-point scale by a person from research team. Stillbirth is defined as a calf born dead or died within 24 hours after birth. Fresh colostrum is harvested within 2 hours after calving, and all calves receive $4 \mathrm{~L}$ of quality colostrum $\geq 50 \mathrm{mg}$ of $1 \mathrm{gG} / \mathrm{dl}$ from their dams or not from their dams, within 3 hours after birth. Two days after colostrum administration, blood samples are collected from jugular vein of female calves to assess failure of passive immune transfer (Brix refractometer; Brix value $\geq 22 \%$ for colostrum quality and Brix value $\geq 8.4 \%$ for adequate immune transfer).

In the first day calves are moved to the calf raising facility and are housed individually. The calves are fed $8 \mathrm{~L}$ of milk twice daily in the morning (4 L) and afternoon (4L).

\subsection{Assessment of Urine PH in Cows}

Testing urine $\mathrm{pH}$ gives a strong indication of the effectiveness of DCAD balancing in the ration. All the cows in the prepartum transition group that have been consuming the transition diet for at least 3 days and are more than 3 
days away from expected calving are selected once per week for urine $\mathrm{pH}$ test. Urine samples are collected between 2 and 4 hours after feeding the diet, by perineal stimulation and free catch of the urine (not at start urinating, because alkaline components in the vagina can cause erroneous results). A portable $\mathrm{pH}$ meter is used that is cleaned, calibrated correctly and rinsed between measurements. Target urine $\mathrm{pH}$ levels in Holstein cows are between 6.0 and 6.8 . If $80 \%$ of the samples are within target, the diet is not adjusting for DCAD. The outlying $20 \%$ is likely caused by improper sampling or one or more of the following factors: eating behavior; feed preferences; adequate amount of feed; forage variability in $\mathrm{K}$ and $\mathrm{Cl}$, overcrowding. Usually a DCAD of -5 to -15 milliequivalents per $100 \mathrm{~g}$ dry matter is used. If the DCAD is not within this range, calcium sulfate or ammonium sulfate is added until sulfur is $0.4-0.5 \%$ of DM or calcium chloride and/or ammonium chloride until DCAD is -5 to $-15 \mathrm{mEq} / 100 \mathrm{~g}$ of DM (Ammonium salts should always be checked for non protein nitrogen levels to avoid ammonia toxicity).

\subsection{Assessment of Calcium Status of Cows}

Blood samples $(8 \mathrm{ml})$ for determination of serum calcium concentration is collected monthly from 4-5 cows within 2 hours after parturition by jugular venipuncture (vacutainer system). After collection blood samples are centrifuged for 20 minutes. Serum sample are stored at $-20^{\circ} \mathrm{C}$ until analyzed, for a longer storage or at $2-8^{\circ} \mathrm{C}$ for 10 days storage.

Total serum concentration of calcium is determined in duplicates, using Calorimetric Method (Calcium OCC Linear Chemicals, S.L.U. Spain).

This method is based on the specific binding of cresolftalein complexone (OCC), a metalochromic indicator and calcium at alkaline $\mathrm{pH}$ with the resulting shift in the absorption wavelength of the complex. The intensity of the chromophore formed is proportional to the concentration of total calcium in the sample.

\subsection{Health Events and Milk Production}

All postpartum cows were screened for retained fetal membranes (RFM), metritis, and mastitis. Retained fetal membranes is defined as a failure to expel the fetal membranes by 24 hours after parturition (LeBlanc et al., 2002). Metritis is defined as a foul-smelling, brown red, watery vaginal discharge within the first 20 days in milk (DIM) with or without fever $\left(\geq 39.5^{\circ} \mathrm{C}\right)$. Clinical mastitis was defined as an inflammation of the udder with visible changes of milk within 20 DIM. Milk production and Somatic Cell Count (SCC), for the first 2 postpartum official milk test were collected from farm records. Survival of lactating dairy cows (died are culled within 60 DIM) was assessed by calcium status at calving.

The incidence of diarrhea in calves was associated with calcium status of the dams of calving. Diarrhea is defined as the presence of fluid or bloody feces (score 2-3 on a 0-3 scale and either $>5 \%$ ) dehydration (score 3, on a 1-3 scale) or fever $\left(\geq 39.5^{\circ} \mathrm{C}\right)$. Within 10 days of age (Goodell et al., 2012). Also survival at 60 days of age was assessed.

\subsection{Breeding Practices}

For all lactating dairy cows the voluntary waiting period (VWP) is 50 to 60 days. The breeding program is based on estrus detection and artificial insemination (AI). Estrus detection is made by daily visual observation and using tail chalk. All cows presenting signs of standing estrus behavior receive AI. The cows that did not display estrus behavior or are not pregnant after 5 consecutive AI are enrolled in a program of induction of estrus and inseminations at an appointed time. Pregnancy diagnosis is performed at $40 \pm 3$ days, post AI via trans rectal palpation. The days in milk at first service and the proportion of pregnancy per AI at first service are recorded.

\subsection{Statistical Analyses}

Data were collected from January $1^{\text {st }} 2017$ to December $31^{\text {st }} 2020$. For this retrospective longitudinal study, data from individual lactating dairy cows were analyzed using Microsoft Office Excel.

The association of cows with hypocalcemia at calving with dystocia, RFM, metritis, culling within 60 DIM and pregnancy at first A, were analyzed using statistical procedures of SAS (SAS Institute, 2009). Also, association of cows with hypocalcemia at calving with days in milk at first service, milk weights $(\mathrm{kg}$ ) components ( $\mathrm{SCC}$ and percent fat and protein were analyzed using MIXED procedure of SAS). The effect of parity BCS at calving were also included. Association of cows with hypocalcemia status at calving with stillbirth, diarrhea within 10 days of age and adequate immune transfer in calves were analyzed.

\section{Results}

In total 431 lactating Holstein Friesian cows (118 primiparous and 313 multiparous) from Research Farm of ARDS Simnic-Craiova were included in the analyses (Table 2). All 431 cows were divided in two groups: Hypo group and non-hypo group (table 2). 
Table 2. Calving calcium profiles and cows health and reproductive parameters performance of dairy cows in hypo and non-hypo groups

\begin{tabular}{lccc}
\hline \multicolumn{1}{c}{ Item } & $\begin{array}{c}\text { Hypo } \\
\mathrm{n}=60\end{array}$ & $\begin{array}{c}\text { Non-hypo } \\
\mathrm{n}=371\end{array}$ & $\mathrm{p}$ - value \\
\hline Calving related events and survival (\%): & & & \\
\hline Dystocia (\%) & 8.3 & 6 & 0.51 \\
RFM (\%) & 12.8 & 5.8 & 0.03 \\
Metritis (\%) & 21.6 & 14 & 0.02 \\
Mastitis (\%) & 11.6 & 8.2 & 0.10 \\
Culled within 60 DIM (\%) & 16.6 & 10.2 & 0.04 \\
\hline Reproductive performances: & \multicolumn{3}{c}{} \\
\hline Days in milk at First service (d) & $86.6 \pm 3.41$ & $82.2 \pm 2.53$ & 0.62 \\
Pregnancy at First service (\%) & 51.6 & 53 & 0.18 \\
\hline
\end{tabular}

In total 60 cows $(13.92 \%)$ had hypocalcemia, using a cut-off value for serum total calcium of $2 \mathrm{mmol} / 1(<8.0$ $\mathrm{mg} / \mathrm{dl}$; Reinhardt et al. 2011).

The overall prevalence of hypocalcemia was $3.4 \%$ for first lactation cows and $18 \%$ for multiparous cows.

\subsection{Health, Culling and Performances of Lactating Cows}

Lactating dairy cows with hypocalcemia had greater proportion of cows with RFM $(p=0.03)$, metritis $(p=0.02)$ and culling within 60 DIM $(\mathrm{p}=0.04$; table 2$)$. The proportion of cows with dystocia $(\mathrm{p}=0.51)$, and mastitis $(\mathrm{p}=$ 0.10 ) was not different between hypo and non-hypo groups of cows (table 2). Also days in milk at first service ( $\mathrm{P}$ $=0.62)$ and pregnancy at first service $(\mathrm{p}=0.18)$ were not different between hypo and non-hypo cows (table 2$)$.

Milk yield $(p=0.40)$, percent milk fat $(p=0.57)$, percent milk protein $(p=0.43)$, and SCC $(p=0.62)$ were not different between hypo and non-hypo cows for the first 2 milk control tests relative to calving (table 3 ).

Table 3. Association of calcium status at calving with milk yield and percent fat and protein, and SCC of Holstein Friesian dairy cows in the first 3 milk control tests relative to calving 1.

\begin{tabular}{lccccc}
\hline \multirow{2}{*}{ Item } & \multicolumn{2}{c}{ Hypo $(\mathrm{n}=60)$} & \multicolumn{2}{c}{ Non-hypo $(\mathrm{n}=371)$} & \multirow{2}{*}{ P - value } \\
\cline { 2 - 5 } & Control 1 & Control 2 & Control 1 & Control 2 & \\
\hline D.I.M. at control test & $28.2 \pm 1$ & $56.6 \pm 2$ & $28.5 \pm 0.9$ & $56.3 \pm 0.4$ & 0.40 \\
Milk yield (kg) & $28.4 \pm 3.1$ & $31.2 \pm 2.8$ & $28.9 \pm 1.2$ & $33.6 \pm 1.0$ & 0.40 \\
Fat (\%) & $3.4 \pm 0.2$ & $3.5 \pm 0.3$ & $3.3 \pm 0.2$ & $3.5 \pm 0.3$ & 0.57 \\
Protein (\%) & $3.0 \pm 0.1$ & $3.1 \pm 0.1$ & $3.1 \pm 0.1$ & $3.2 \pm 0.1$ & 0.43 \\
SCC x 10 cells/ml of milk & $249 \pm 110$ & $200 \pm 98$ & $256 \pm 108$ & $188 \pm 90$ & 0.62 \\
\hline
\end{tabular}

1 Least squares means are presented \pm SEM;

Hypo: cows with $\leq 8.0 \mathrm{mg} \mathrm{Ca} / \mathrm{dl}$; non-hypo: cows $\geq 8.1 \mathrm{mg} \mathrm{Ca} / \mathrm{dl}$.

\subsection{Calf Diarrhea within 10 Days of Age and Survival within 60 Days of Age in Calves}

The proportion of stillborn calves $(\mathrm{P}=0.38)$ and survival within 60 days of age $(\mathrm{P}=0.41)$, did not differ between hypo and non-hypo cows (table 4).

Calves born by hypo cows had a significantly greater $(\mathrm{P}=0.04)$ incidence of diarrhea compared with non-hypo cows (table 4).

Table 4. Association of calcium status at calving with stillbirth, diarrhea 10 days of age and survival within 60 days of age in calves.

\begin{tabular}{lccc}
\hline \multicolumn{1}{c}{ Item $^{1}$} & Hypo $(\mathrm{n}=60)$ & Non-hypo $(\mathrm{n}=371)$ & $\mathrm{P}-$ value \\
\hline Stillbirth $^{2}(\%)$ & 3.3 & 2.6 & 0.38 \\
Diarrhea (\%) & 38.3 & 22.3 & 0.04 \\
Survival (\%) & 92 & 95 & 0.41 \\
\hline
\end{tabular}


In the present study the overall prevalence of hypocalcemia clinical and subclinical combined was $3.4 \%$ for primiparous and $18 \%$ for multiparous cows.

For vital bodily functions is necessary ionized calcium. Kimura et al., 2006 reported that the extracellular calcium status is the primary determinant of intracellular calcium status. The immunosuppression observed in postpartum dairy cows is likely due to the decreased storage of intracellular ionized Ca (Martinez et al., 2012).

The depletion of intracellular calcium stores starts several days before parturition and development of hypocalcemia in early postpartum dairy cows.

Calcium concentrations are reported to reach a nadir within 12 to 24 hours after parturition (Goff, 2008) thus, the prevalence of hypocalcemia in cows by 24 hours after calving may be higher than reported in this study. Martinez et al., 2012, reported that cows with subclinical hypocalcemia (total serum calcium $\leq 8.59 \mathrm{mg} / \mathrm{dl}$ ) for at least one day, between 0 and 3 DIM had less neutrophils in their blood with reduced functions, and increased risk for metritis. In the present study, hypo cows had significantly increased risk for RFM, metritis and culling within 60 DIM as compared to non-hypo cows.

Jawor et al., 2012, reported that cows with hypo $(<7.2 \mathrm{mg} / \mathrm{dl})$ produced $5.7 \mathrm{~kg} /$ day more milk. Martinez et al., 2012 , reported that milk production did not differ between hypo $(\leq 8.59 \mathrm{mg} / \mathrm{dl})$ and non-hypo cows.

In this study milk yield and components as well as SCC for the first 2 official milk control tests were not different in hypo and non-hypo cows.

An interesting finding was that calves born from hypo cows had a greater proportion of diarrhea within 10 days of age compared to those born from non-hypo cows. The most efficient and effective management of the newborn health is achieved by feeding adequate quantity (4 l) of quality colostrum ( $\geq 50 \mathrm{~g} / \mathrm{L} \mathrm{IgG}$ ) and minimal bacterial contamination within first 3 hours after birth (Mee, 2008). Immediately after birth calf require proper navel disinfection, removal from the dam and movement to a clean and dry environment. In this study hypo cows tended to yield colostrum of inferior concentration of IgG compared with non-hypo cows which in turn could compromise, in past, neonatal calf health within 10 days of age. Further studies are needed to assess the association between calcium and energy status at calving of dam and neonatal calf health, accounting for effect of colostrum components (IgG, vitamins and nutrients).

\section{Conclusions}

Overall the present study indicates that hypocalcemia is a metabolic disorder in the dairy farm analyzed, as $3.4 \%$ of first lactation cows and $18 \%$ of multiparous cows suffered from this metabolic disorder.

Findings from this study show that hypocalcemia of dairy cows at calving has significant health implications for both dams and their calves.

\section{References}

Martin-Tereso, J., \& Holger Martens, V. M. D. (2014). Calcium and magnesium physiology and nutrition in relation to the prevention of milk fever and tetany (dietary management of micro minerals in preventing disease). Vet. Clinics North America Food Anim. Practice, 30, 643-670. https://doi.org/10.1016/j.cvfa.2014.07.007

Goff, J. P. (2008). The monitoring prevention, and treatment of milk fever and subclinical hypocalcemia in dairy cows. Vet., 176, 50-57. https://doi.org/10.1016/j.tvj1.2007.12.020

Goff, J. P., El-Samad, H., \& Khammash, M. (2000). Calcium homeostasis. A feedback control point of view. Proceeding of the American Control Conference, Chicago, Illinois, June 2000, p: 2962-2966. http://dx.doi.org/10.1109/ACC.2000.879108

Sjaastad, O. V., Hove, K., \& Sand, O. (2003). Physiology of Domestic animals, 237, 248-249. Oslo: Scandinavian Veterinary Press. ISBN: 9788-2917-4397-3.

Ramberg, Jr C., Mayer, F., Kronfeld, G., Phang, D. J., \& Berman, M. (1970). Calcium kinetics in cows during late pregnancy, parturition and early lactation. An. J. Physiol, 219, 1166-1177. https://oi.org/10.1152/ajplegacy.1970.219.5.1166

Martin-Tereso J., \& Verstegen, M. V. A. (2011). A novel model to explain dietary factors affecting hypocalcaemia in dairy cows. Journals Nutrition Research Reviews, 24(2). https://doi.org/10.1017/s0954422411000126

Hoenderop J. G. L., Nilius, B., \& Bindels, R. J. M. (2005). Calcium absorption across epithelia. Physiol. Rev., 85, 373-422. https://doi.org/10.1152/physrev.00003.2004 
Bouillon, R., Cromphaut, S. Van, \& Carmeliet, G. (2003). Intestinal calcium absorption: molecular vitamin D mediated mechanisms. Cell Biochem, 88, 332-339. https://doi.org/10.1002/jcb.10360

Bronner, F. (2003). Mechanisms of intestinal calcium absorption. J. Cell Biocehm, 88, 383-393. https://doi.org/10.1002/jcb.10330

Khanal, R., \& Nemere, I. (2008). Regulation of intestinal calcium transport. Annu. Rev. Nutr, 28, 179-196. https://doi.org/10.1146/annurev.nutr.010308.161202

Suzuki, Y., Landowski, C., \& Hediger, M. (2008). Mechanism and regulation of epithelial Ca2+ absorption in health and disease. Annual Rev. Physiol., 70, 257-271. https://doi.org/10.1146/annurev.physiol.69.031905.161003

Schonewille, I. A., \& Van't Klooster, et al. (1994). Stimulatory effect of an anion (chloride) - rich ration on apparent calcium absorption in dairy cows. Livest. Prod. Sci., 40, 233-240. https://doi.org/10.1016/03016226(94)90091-4

Roche I. D., Dalley, P., \& Moate, et al. (2003). Dietary cation-anion differences and the health and production of pasture-fed daily cows 2. Nonlactating periparturient cows. J. Dairy Sci., 86, 979-987. https://doi.org/10.3168/jds.s0022-0302(03)73681-9

Parfitt A., (1976). The actions of parathyroid hormone on bone: relation to bone remodeling and turnover, calcium homeostasis, and metabolic bone disease. Part III of IV parts; PTH and osteoblasts, the relationship between bone turnover and bone loss, and the state of the bones in primary hyperparathyroidism. Metabolism, 25, 909955. https://doi.org/10.1016/0026-0495(76)90133-5

Bauman, D. E., \& Bruce Currie, W. (1980). Partitioning of nutrients during pregnancy and lactation: a review of mechanisms involving homeostasis and homeorhesis. J. Dairy Sci., 63, 1514-1529. https://doi.org/10.3168/jds.S0022-0302(80)83111-0

Lean I., DeGaris, P., \& McNeil D. et al. (2006). Hypocalcemia in dairy cows: meta-analysis and dietary cation anion difference theory revisited. J. Dairy Sci., 89, 669-684. https://doi.org/10.3168/jds.s00220302(06)72130-0

Martinez, N., Risco, C. A., Lima, F. S., Bisinotto, R. S., Greco, L. F., Ribeiro, E. S., ... Santos, K. N. (2012). Evaluation of peripartal calcium status, energetic profile and neutrophil function in dairy cows at low or high risk of developing uterine disease. J. Diary Sci., 95, 7158-7172. https://doi.org/10.3168/jds.2012-5812

Ribeiro, E. S., Lima, F. S., Greco, L. F., Bisinotto, R. S., Monteiro, A. P., Favoreto, M., .... Santos, J. E. (2013). Prevalence of periparturient diseases and effects on fertility of seasonally calving grazing dairy cows supplemented with concentrates. J. Dairy Sci., 96, 5682-5697. https://doi.org/10.3168/jds.2012-6335

Caixeta, L. S., Ospina, P. A., Capel, M. B., \& Nydam, D. V. (2017). Association between subclinical hypocalcemia in the first 3 days of lactation and reproductive performance of dairy cows. Theriogenology, 94, 1-7. https://doi.org/10.1016/j.theriogenology.2017.01.039

Chapinal, N., Carson, M. E., LeBlanc, S. J., Leslie, L. E., Godden, S., Capel, M., ... Duffield, T. F. (2012). The association of serum metabolites in the transition period with milk production and early-lactation reproductive performance. J. Dairy Sci., 95, 1301-1309. https://doi.org/10.3168/jds.2011-4724

Planski, B., \& Abrashev, N. (1987). Dynamic aspects of mineral metabolism in dry cows, puerperants and calves. Vet. Med. Namki, 24, 48-57.

LeBlanc S. J., Leslie, K. E., Duffield, T. F., Bateman, K. G., TenHag, J., Walton, J. S., \& Johnson, W. H. (2002). The effect of prepartum injection of vitamin E on health in transition dairy cows. J. Dairy Sci., 85, 1416-1426. https://doi.org/10.3168/jds.s0022-0302(02)74209-4

Goodell G. M., Campbell, L. J., Hoejvang-Nielsen, Stansen, W., \& Constable, P. D. (2012). An alkalinizing oral rehydration solution contained lecithin-coated citrus fiber is superior to a nonalkalinizing solution in treating 360 calves with naturally acquired diarrhea. J. Dairy Sci., 95, 6677-6686. https://doi.org/10.3168/jds.20125605

Reinhardt T. A., J. D. Lippolis, B. J. McCluskey, Goff, J. P., \& Horst, R. L. (2011). Prevalence of subclinical hypocalcemia in dairy herds. Vet. J., 188, 122-124. https://doi.org/10.1016/j.tvj1.2010.03.025

Kimura K., Reinhardt, T. A., \& Goff, J. P. (2006). Parturition and hypocalcemia blunts calcium signals and immune cells of dairy cattle. J. Dairy Sci., 89, 2588-2595. https://doi.org/10.3168/jds.s0022-0302(06)72335-9 
Jawor, P. E., Huzzey, J. M., LeBlanc, S. J., \& Keyserlingk, M. A. (2012). Association of subclinical hypocalcemia at calving with milk yield, and feeding, drinking, and standing behaviors around parturition in Holstein cows. J. Dairy Sci., 95, 1240-1248. https://doi.org/10.3168/jds.2011-4586

Mee, J. F. (2008). Prevalence and risk factors for dystocia in dairy cattle: A review. The Veterinary, 17, 93-101. https://doi.org/10.1016/j.tvj1.2007.12.032

\section{Copyrights}

Copyright for this article is retained by the author(s), with first publication rights granted to the journal.

This is an open-access article distributed under the terms and conditions of the Creative Commons Attribution license (http://creativecommons.org/licenses/by/4.0/). 